\title{
Secondary necrosis of apoptotic neutrophils induced by the human cathelicidin LL-37 is not proinflammatory to phagocytosing macrophages
}

\author{
Hsin-Ni Li,* Peter G. Barlow, * Johan Bylund, ${ }^{\dagger}$ Annie Mackellar,* Åse Björstad, ${ }^{\dagger}$ \\ James Conlon, ${ }^{*}$ Pieter S. Hiemstra, ${ }^{\ddagger}$ Chris Haslett, ${ }^{*}$ Mohini Gray, ${ }^{*}$ A. John Simpson, * \\ Adriano G. Rossi,* and Donald J. Davidson*,1
}

*MRC/University of Edinburgh Centre for Inflammation Research, Queen's Medical Research Institute, Edinburgh, Scotland; ${ }^{\dagger}$ Rheumatology Department, University of Gothenburg, Sweden; and ${ }^{\ddagger}$ Department of Pulmonology, Leiden University Medical Center, The Netherlands

RECEIVED FEBRUARY 2, 2009; REVISED MAY 14, 2009; ACCEPTED MAY 16, 2009. DOI: 10.1189/jlb.0209050

\begin{abstract}
Cathelicidins are CHDP with essential roles in innate host defense but also more recently associated with the pathogenesis of certain chronic diseases. These peptides have microbicidal potential and the capacity to modulate innate immunity and inflammatory processes. PMN are key innate immune effector cells with pivotal roles in defense against infection. The appropriate regulation of PMN function, death, and clearance is critical to innate immunity, and dysregulation is implicated in disease pathogenesis. The efferocytosis of apoptotic PMN, in contrast to necrotic cells, is proposed to promote the resolution of inflammation. We demonstrate that the human cathelicidin LL-37 induced rapid secondary necrosis of apoptotic human PMN and identify an essential minimal region of LL-37 required for this activity. Using these LL-37-induced secondary necrotic PMN, we characterize the consequence for macrophage inflammatory responses. LL-37-induced secondary necrosis did not inhibit PMN ingestion by monocyte-derived macrophages and in contrast to expectation, was not proinflammatory. Furthermore, the anti-inflammatory effects of apoptotic PMN on activated macrophages were retained and even potentiated after LL-37-induced secondary necrosis. However, this process of secondary necrosis did induce the release of potentially harmful PMN granule contents. Thus, we suggest that LL-37 can be a potent inducer of PMN secondary necrosis during inflammation without promoting macrophage inflammation but may mediate host damage through PMN granule content release un-
\end{abstract}

\footnotetext{
Abbreviations: $\mathrm{AV}=\mathrm{Annexin} \mathrm{V}, \mathrm{BALF}=$ bronchoalveolar lavage fluid, $\mathrm{CD} 4 \mathrm{OL}=\mathrm{CD} 4 \mathrm{O}$ ligand, $\mathrm{CHDP}=$ cationic host defense peptide(s) $\mathrm{DC}=$ dendritic cell, hCAP-18=human cationic antimicrobial protein, $L A L=$ Limulus amoebocyte lysate, $m C R A M P=$ mouse cathelicidin antimicrobial peptide, $\mathrm{MDM}=$ monocyte-derived macrophage(s), $\mathrm{MPO}=$ myeloperoxidase, $\mathrm{Pl}=$ propidium iodide, $\mathrm{PMN}=$ polymorphonuclear granulocytes, TEM=transmission electron microscopy
}

der chronic or dysregulated conditions. J. Leukoc. Biol. 86: 891-902; 2009.

\section{Introduction}

PMN are important first-line innate immune cells, which are mobilized rapidly in response to infection and injury. However, the arsenal of products used by PMN to destroy microbes is also potentially deleterious to host cells. Appropriate regulation of PMN influx, activation, death, and removal is therefore critical, and dysregulation of these processes has been implicated in the pathogenesis of chronic lung diseases [1, 2].

PMN have a short half-life and undergo spontaneous apoptosis. This programmed and regulated form of cell death enables recognition, ingestion, and removal by macrophages or DCs, a process involving multiple receptors and adaptors [3]. Efferocytosis (the uptake of apoptotic cells) can protect the host from the release of toxic PMN intracellular contents and induce anti-inflammatory and immunosuppressive effects. These include dampening the LPS-induced, proinflammatory cytokine response and enhancing anti-inflammatory responses by macrophages [4-6]. These processes, in addition to an active switch in the lipid mediators generated to the production of lipoxins, resolvins, and protectins [7], can stimulate the resolution of inflammation. However, in the absence of efferocytosis, apoptotic PMN will undergo secondary necrosis with loss of membrane integrity. Although necrosis is typically regarded as proinflammatory [1], the effect of PMN secondary necrosis on inflammation and the mechanisms of clearance of these

1. Correspondence: MRC/University of Edinburgh Centre for Inflammation Research, Queen's Medical Research Institute, W2.05, 47 Little France Crescent, Edinburgh EH16 4TJ, Scotland. E-mail: donald.davidson@ed.ac.uk

This is an Open Access article distributed under the terms of the Creative Commons Attribution Non-Commercial License (http://creativecommons.org/ licenses/by-nc/3.0/us/) which permits unrestricted non-commercial use, distribution, and reproduction in any medium, provided the original work is properly cited. 
cells are relatively poorly understood. Further understanding of these issues is of great significance to evaluate the impact of delayed PMN clearance in the resolution of inflammation.

The survival and death of PMN can be modulated significantly by the inflammatory milieu, including cytokines such as TNF- $\alpha$ and GM-CSF, TLR agonists (e.g., LPS), and bacterial products (e.g., pyocyanin) [8], in addition to potential therapeutic modulators [9]. The human CHDP (also known as antimicrobial peptide) LL-37 can also modulate PMN death pathways in vitro $[10,11]$. We have demonstrated that LL-37 promotes PMN necrosis at the expense of apoptosis [10]. However, the mechanisms involved and the consequences for inflammation remain to be determined.

CHDP are key evolutionarily conserved components of innate host defense systems, which are being modified and developed as novel, antimicrobial therapeutic agents. The two major CHDP families in vertebrates are defensins and cathelicidins. LL-37 is the predominant, mature cationic peptide fragment of the sole human cathelicidin hCAP-18, which is found at high concentration in neutrophil specific granules and is cleaved to its active form by proteinase-3 $[12,13]$. LL-37 is also produced by epithelial cells from a variety of tissues in response to infectious and inflammatory stimuli and is expressed by macrophages and other leukocytes [14]. In addition to direct microbicidal potential, LL-37 has a broad range of immunomodulatory functions including antiendotoxic activity and chemotactic function, modulation of chemokine and cytokine responses, promotion of cell wound-healing and angiogenesis, modulation of DC differentiation and function, and the capacity to modulate cell death pathways $[10,11,15-27]$. In vivo evidence in humans and mice supports a critical role in innate defense [28-31], hCAP-18/LL-37 concentration in BALF is increased significantly in human lung infections [32], and overexpression of LL-37 in the murine lung enhanced the clearance of infection [33]. However, increased levels of hCAP-18/LL-37 have also been associated with and implicated in chronic disease processes [34-36]. Thus, despite a fundamental role in innate defense, dysregulated control of LL-37 may be detrimental to the host. The key immunomodulatory properties that contribute to the physiological role of LL-37 in host defense and how these might contribute to disease pathogenesis when dysregulated remain unresolved.

We hypothesized that LL-37-induced necrosis of PMN could alter efferocytosis and the nature of the subsequent inflammatory response and could lead to the release of potentially damaging PMN intracellular contents. To examine the role of LL37-induced PMN necrosis on the inflammatory response, we characterized the dynamics of LL-37-induced PMN necrosis before evaluating the effect of LL-37-induced PMN necrosis on efferocytosis and macrophage inflammatory responses and the consequences for release of PMN intracellular contents.

\section{MATERIALS AND METHODS}

\section{Reagents}

rhGM-CSF was purchased from Research Diagnostics Inc. (Flanders, NJ, USA). $R$-Roscovitine was supplied by A. G. Scientific (San Diego, CA,
USA). Ultra-pure LPS from the Escherichia coli 0111:B4 strain was purchased from InvivoGen (San Diego, CA, USA). Dexamethasone was purchased from Organon Laboratories Ltd. (Cambridge, UK). rhCD40L and IFN- $\gamma$ were purchased from PeproTech ED Ltd. (London, UK). LL-37 (LLGDFFRKSKEKIGKEFKRIVQRIKDFLRNLVPRTES) and mCRAMP (GLLRKGGEKIGEKLKKIGQKIKNFFQKLVPQPEQ) were synthesized by $\mathrm{N}$-(9-fluorenyl) methoxycarbonyl chemistry at the Nucleic Acid/Protein Service Unit at the University of British Columbia (Canada), as described previously [10]. Peptides were purified by reverse-phase HPLC and were at least $98 \%$ pure. The concentration of the peptides in solution was determined by amino acid analysis. Scrambled LL-37 (RSLEGTDRFPFVRLKNSRKLEFKDIKGIKREQFVKIL) was purchased from CSS-Albachem Ltd. (Gladsmuir, Scotland, UK), and the panel of 16 overlapping 22-mer partial LL-37 peptides (from N-terminal peptide LLGDFFRKSKEKIGKEFKRIVQ through to C-terminal peptide EFKRIVQRIKDFLRNLVPRTES) was synthesized by Jan W. Drijfhout at Leiden University Medical Center (The Netherlands) as described previously [37]. Peptides were dissolved in endotoxin-free water (Sigma-Aldrich, Poole, UK) and stored at $-20^{\circ} \mathrm{C}$ until further use. All reagents were tested using a LAL kinetic-quantitative chromogenic LAL assay (Cambrex, Walkersville, MD, USA) to ensure they were free of endotoxin and reconstituted in endotoxin-free water.

\section{Isolation of human blood neutrophils}

Human venous blood was collected according to Lothian Research Ethics Committee approval \#08/S1103/38 or \#1702/95/4/72 using sodium citrate anticoagulant (Phoenix Pharma Ltd., Gloucester, UK), and cells were separated by Dextran sedimentation, followed by discontinuous, isotonic Percoll gradient centrifugation as described previously [10]. Granulocytes were washed in PBS without calcium or magnesium (PAA Laboratories, Somer set, UK) and resuspended in IMDM (PAA Laboratories) with $10 \%$ FCS (Biosera, East Sussex, UK). Purity was assessed by morphological criteria using cytocentrifuge preparations and FACS analyses and antibodies against human CD16 (Caltag-Medsystems Ltd., Towcester, UK) and CD66b (BD Biosciences, San Diego, CA, USA) to distinguish PMN from eosinophils and against CD14, CD4, CD8, and CD19 (Caltag-Medsystems Ltd.). Granulocyte purity of $>98 \%$ was yielded by this method, and granulocytes were typically 95-98\% PMN. However, high eosinophil donors were also studied, demonstrating no significant effect of eosinophil number on LL-37-induced secondary necrosis of apoptotic PMN. Total cell number was assessed by hemacytometer counts and by NucleoCounter YC-100 (ChemoMetec, Allerød, Denmark) automated cell number counting.

\section{Assessment of PMN death}

Freshly isolated PMN were incubated at $37^{\circ} \mathrm{C}, 5 \% \mathrm{CO}_{2}$, at $5 \times 10^{6} / \mathrm{ml}$ in IMDM with $10 \%$ (v/v) FCS in the presence of LL-37, GM-CSF, R-Roscovitine, LPS, mCRAMP, scrambled LL-37, or partial LL-37 peptides at the stated concentrations or in control media in triplicate over the time periods detailed. To induce primary necrosis, freshly isolated cells were heated at $65^{\circ} \mathrm{C}$ for $30 \mathrm{~min}$. Cell death was assessed by light microscopic evaluation of apoptotic morphology as described [10] and also by examining cells stained at $4^{\circ} \mathrm{C}$ with FITC-labeled AV (Roche Applied Sciences, West Sussex, UK), diluted 1:2000 in HBSS with $5 \mathrm{mM} \mathrm{CaCl}_{2}$, and 3 $\mu \mathrm{g} / \mathrm{ml}$ PI (Invitrogen Ltd., Paisley, UK) for flow cytometric evaluation using a FACSCalibur, counting $\geq 10,000$ cells, and analyzed using FloJo software (TreeStar Inc., Ashland, OR, USA). High concentrations of LL-37 can lead to a complete loss of cells from analysis $[10,38]$. To evaluate this accurately, the concentrationdependent induction of necrosis was determined by FACS, and the total detectable PMN numbers were determined using a NucleoCounter YC-100 (ChemoMetec) after $20 \mathrm{~h}$ culture over a range of LL-37 concentrations $(\leq 25 \mu \mathrm{g} / \mathrm{ml})$. An approximate $\mathrm{EC}_{50}=3.8 \mu \mathrm{g} / \mathrm{ml}$ was determined for LL-37-induced necrosis, and LL-37 $\geq 10 \mu \mathrm{g} / \mathrm{ml}(\sim 2 \mu \mathrm{M})$ was found to induce a significant and concentrationdependent loss in total detectable cell number (total cell number as a proportion of control sample $=81 \% \pm 5 \%$ at $20 \mathrm{~h}, \mathrm{LL}-3710 \mu \mathrm{g} / \mathrm{ml} ; P<0.01 ; n=20)$. In contrast, incubation with $\leq 5 \mu \mathrm{g} / \mathrm{ml}$ LL-37 did not result in a significant decrease, although a degree of cell loss was observed sometimes. LL-37 was therefore used at $\leq 5 \mu \mathrm{g} / \mathrm{ml}$ for further studies examining LL-37-mediated modulation of PMN cell death. 


\section{TEM}

Freshly isolated PMN were incubated with or without $5 \mu \mathrm{g} / \mathrm{ml}$ LL-37 for $20 \mathrm{~h}$, as described above, centrifuged at $250 \mathrm{~g}$ for $5 \mathrm{~min}$ at room temperature, and resuspended gently in $1 \mathrm{ml} 2.5 \%$ glutaraldehyde (Sigma-Aldrich) in $0.1 \mathrm{M}$ sodium cacodylate buffer, $\mathrm{pH} 7.3$ (Sigma-Aldrich), for $1 \mathrm{~h}$. Cells were washed in three 10-min changes of $0.1 \mathrm{M}$ sodium cacodylate and postfixed in $1 \%$ osmium tetroxide in $0.1 \mathrm{M}$ sodium cacodylate for $45 \mathrm{~min}$ before three 10-min changes of $0.1 \mathrm{M}$ sodium cacodylate. Samples were then dehydrated in $50 \%, 70 \%, 90 \%$, and $100 \%$ normal grade acetones before two 10-min changes in analar acetone and embedded in Araldite resin. Toluidine blue-stained sections $(1 \mu \mathrm{m})$ were previewed before $60 \mathrm{~nm}$ ultrathin sections were cut from selected areas, stained in uranyl acetate and lead citrate, and then viewed in a Philips CM120 transmission electron microscope (FEI UK Ltd., Cambridge, UK). Images were taken on a Gatan Orius charged-coupled device camera (Gatan UK, Oxon, UK).

\section{Western immunoblotting}

Freshly isolated PMN were incubated as described above over a range of LL-37 concentrations. At Time $0 \mathrm{~h}$ or after $20 \mathrm{~h}$, cells were washed with PBS without $\mathrm{Ca}^{2+}$ and $\mathrm{Mg}^{2+}$, and proteins were extracted using Mammalian Protein Extraction Reagent (Pierce/Perbio Science UK, Cheshire, UK) containing $30 \mu \mathrm{l} / \mathrm{ml} \mathrm{Halt}{ }^{\mathrm{TM}}$ protease inhibitor cocktail, $30 \mu \mathrm{l} / \mathrm{ml} \mathrm{Halt}^{\mathrm{TM}}$ phosphatase inhibitor cocktail, $10 \mu \mathrm{l} / \mathrm{ml}$ EDTA solution (all Pierce/Perbio Science UK), $30 \mu \mathrm{M}$ pepstatin (Sigma-Aldrich), and $10 \mu \mathrm{M}$ lactacystin (Calbiochem/Merck Biosciences Ltd., Nottingham, UK). Total protein concentrations were determined by bicinchoninic acid assay (Pierce/Perbio Science UK). Equivalent total protein $(20-50 \mu \mathrm{g})$ was resolved in Pierce Precise gels (Pierce/Perbio Science UK) transferred to Immun-Blot polyvinylidene difluoride membranes (Bio-Rad Laboratories, Hercules, CA, USA) and immunoblotting performed as described [10] with anti-human cleaved caspase-3 rabbit polyclonal antibody and reprobed with antipan-actin antibody (both Cell Signaling Technology, Beverly, MA, USA) for protein loading correction via densitometric analysis using ImageJ software (National Institutes of Health, Bethesda, MD, USA).

\section{Phagocytic studies}

Human PBMC were isolated by isotonic Percoll gradient centrifugation as described above and incubated at $4 \times 10^{6} / \mathrm{ml}$ in IMDM at $37^{\circ} \mathrm{C}, 5 \% \mathrm{CO}_{2}$, for $1 \mathrm{~h}$. Nonadherent cells were removed and adherent monocytes cultured for 5-7 days in IMDM and 10\% autologous serum to generate MDM. For light microscopic analyses of phagocytosis, PMN were incubated previously for $20 \mathrm{~h}$, with or without LL-37 (or scrambled LL-37) at the stated concentrations (as described above), and the level of apoptosis was assessed as described. PMN $\left(2.5 \times 10^{6} ; \sim 2.5: 1\right.$ ratio of PMN:MDM) were overlaid onto HBSS-washed MDM monolayers for $1 \mathrm{~h}$ at $37^{\circ} \mathrm{C}$. MDM were then washed gently four times with IMDM to remove noningested PMN and fixed with $2.5 \%$ paraformaldehyde (Sigma-Aldrich) for $10 \mathrm{~min}$. PMN MPO was stained with $0.1 \mathrm{mg} / \mathrm{ml}$ dimethoxybenzidine (Sigma-Aldrich) and $0.03 \%(\mathrm{v} / \mathrm{v}) \mathrm{H}_{2} \mathrm{O}_{2}$ (Sigma-Aldrich) before analysis by light microscopy, counting at least $200 \mathrm{MDM}$ in five randomly selected fields of view to evaluate the proportion of MDM-containing peroxidase-positive cells, with $n=2$ replicates/experiment. Only MDM that had engulfed PMN clearly were scored as positive. For flow cytometric analyses of phagocytosis, freshly isolated PMN were stained with Cell Tracker Green (Molecular Probes, Eugene, $\mathrm{OR}, \mathrm{USA}$ ) at $37^{\circ} \mathrm{C}$ for $20 \mathrm{~min}$, according to the manufacturer's instructions, and then washed twice with PBS before incubation for $20 \mathrm{~h}$ in the presence or absence of LL-37, as described. The effects of LL-37 were not altered by Cell Tracker Green staining (data not shown). MDM were exposed to PMN as described above, but after $1 \mathrm{~h}$ incubation, cells were detached and collected using $0.05 \%$ trypsin/0.02\% EDTA solution (Cambrex). Samples were analyzed by FACSCalibur as described previously [39], with $n=2$ replicates/experiment. The number of Cell Tracker Green-positive events in the macrophage gate (based on forward- and side-scatter) represented the number of macrophages that had ingested PMN and was evaluated as a proportion of total number of MDM. As a positive control, wells of adher- ent monocytes were also cultured in the presence of $1 \mu \mathrm{M}$ dexamethasone for 5 days, a process demonstrated previously to up-regulate MDM phagocytosis of dead PMN [40].

\section{MDM cytokine production}

Freshly isolated PMN at $5 \times 10^{6} / \mathrm{ml}$ were incubated for $20 \mathrm{~h}$ in the presence or absence of LL-37, scrambled LL-37, or partial LL-37 peptides $\mathrm{p} 1$ (LLGDFFRKSKEKIGKEFKRIVQ), p2 (KIGKEFKRIVQRIKDFLRNLVP), or p3 (EFKRIVQRIKDFLRNLVPRTES) at the concentrations indicated in 10\% FCS as described above. Samples $(1 \mathrm{ml})$ were collected and each split in two, and half of each sample was centrifuged at $230 \mathrm{~g}$ before collection of the supernatant and resuspension of the cells in $0.5 \mathrm{ml} \mathrm{X}$-vivo 10 media (Lonza Biologics, Slough, UK), with or without $10 \%$ FCS. Washed MDM, with or without concomitant exposure to $10 \mathrm{ng} / \mathrm{ml} \mathrm{E}$. coli 0111:B4 LPS or 3 $\mu \mathrm{g} / \mathrm{ml} \mathrm{rhCD} 40 \mathrm{~L} / 5 \mathrm{ng} / \mathrm{ml} \mathrm{rhIFN}-\gamma$, were then incubated at $37^{\circ} \mathrm{C}, 5 \% \mathrm{CO}_{2}$, for $18 \mathrm{~h}$ with $0.5 \mathrm{ml}$ PMN in fresh X-vivo 10, PMN in the original IMDM with $10 \%$ FCS, IMDM with $10 \%$ FCS supernatant collected from overnightincubated PMN, or media alone. MDM alone and PMN alone in the presence of absence of LPS and/or LL-37 were also studied as controls. Supernatants were collected, centrifuged at $230 \mathrm{~g}$ for $6 \mathrm{~min}$ to remove cells and particulate debris, and then stored in aliquots at $-70^{\circ} \mathrm{C}$. The concentrations of TNF- $\alpha$, IL-6, IL-10, IL-12p70, and IL-1 $\beta$ in the supernatants were measured using BD Cytometric Bead Array human inflammation kits with a BD FACSArray (BD Biosciences) or Human TNF- $\alpha$ DuoSet ELISA (R\&D Systems, Minneapolis, MN, USA), according to the manufacturer's instructions.

\section{MPO release}

Freshly isolated PMN were incubated with different concentrations of LL-37 or scrambled peptide for $20 \mathrm{~h}$ as described above, centrifuged at 230 $g$ for $6 \mathrm{~min}$, and placed immediately on ice, and the supernatants were collected. To detect MPO, $100 \mu \mathrm{l}$ supernatant samples (used neat or diluted in PBS) were incubated in the dark for $20 \mathrm{~min}$ at room temperature with $100 \mu$ l substrate solution (1:1 mixture of $\mathrm{H}_{2} \mathrm{O}_{2}$ and tetramethylbenzidine; R\&D Systems), followed by addition of $50 \mu 12 \mathrm{~N} \mathrm{H}_{2} \mathrm{SO}_{4}$ stop solution and colorimetric analyses at $450 \mathrm{~nm}$ using a microplate reader. The concentration of MPO in the supernatants was evaluated as a percentage of MPO release after complete lysis of fresh control PMN using $0.1 \%$ Triton X-100 (Sigma-Aldrich).

\section{Statistical analysis}

GraphPad Prism 5 statistical software was used to determine statistical significance. One-way or two-way ANOVA with Bonferroni's multiple comparison post-tests or Student's $t$-tests was performed as appropriate. $P<0.05$ was considered significant. Values are expressed as mean \pm SEM.

\section{RESULTS}

\section{LL-37 induces the rapid secondary necrosis of apoptotic PMN}

We and others $[10,11]$ have demonstrated that the proportion of apoptotic $\left(\mathrm{AV}^{+} \mathrm{PI}^{-}\right)$cells detected in an in vitro model of spontaneous apoptosis of human PMN was decreased significantly when cells were cultured with LL-37. The most prominent consequence of this was an increased proportion of necrotic $\left(\mathrm{AV}^{+} \mathrm{PI}^{+}\right)$PMN [10]. To carefully characterize LL37-induced, necrotic PMN, with which to examine the consequences for macrophage inflammatory responses, a large donor pool ( $n=28$ different donors) was evaluated. This demonstrated the concentration-dependent capacity of LL-37 to promote PMN necrosis significantly at the expense of apoptosis, with no signifi- 
cant impact on the proportion of live $\left(\mathrm{AV}^{-} \mathrm{PI}^{-}\right)$cells at $\leq 5$ $\mu \mathrm{g} / \mathrm{ml}$ LL-37 using FACS (Fig. 1A) and morphological analyses. LL-37-induced necrotic PMN were observed to be similar to "late apoptotic" cells observed in control samples at $20 \mathrm{~h}$, with less-severe loss of membrane integrity than primary necrosis induced by heat treatment of cells (Fig. 1B). TEM was used to confirm the capacity of LL-37 to promote PMN necrosis after $20 \mathrm{~h}$ incubation when compared with control cells (Fig. 1, C and D).

We have demonstrated previously that LL-37 was not lytic to PMN [10]. Furthermore, no significant necrosis was observed at $0,1,4$, or $6 \mathrm{~h}$ (ref. [10], and data not shown). However, significant $(P \leq 0.001)$ induction of necrosis was observed at $12 \mathrm{~h}$ (data not shown) and thereafter, occurring at time-points at which substantial apoptosis was observed. In keeping with recent publications $[38,41]$, this suggested prior induction of apoptosis may be necessary and that LL-37 might induce secondary necrosis. To confirm this in our model system, PMN were exposed to early or late pulses of LL-37. PMN incubated with LL-37 ( $\leq 5 \mu \mathrm{g} / \mathrm{ml})$ for $4 \mathrm{~h}$, followed by washing and incubation in control media for $16 \mathrm{~h}$, had proportions of apoptotic, necrotic, and live cells identical to untreated controls (data not shown). In contrast, $20 \mathrm{~h}$ incubation of cells in control media, followed by exposure to LL-37 for just 10 min before FACS analyses, completely replicated the dose-dependent effect of $20 \mathrm{~h}$ incubation with LL-37 (Fig. 1E), demonstrating that LL-37 induced a rapid secondary necrosis of apoptotic $\mathrm{PMN}$ without affecting live cells.
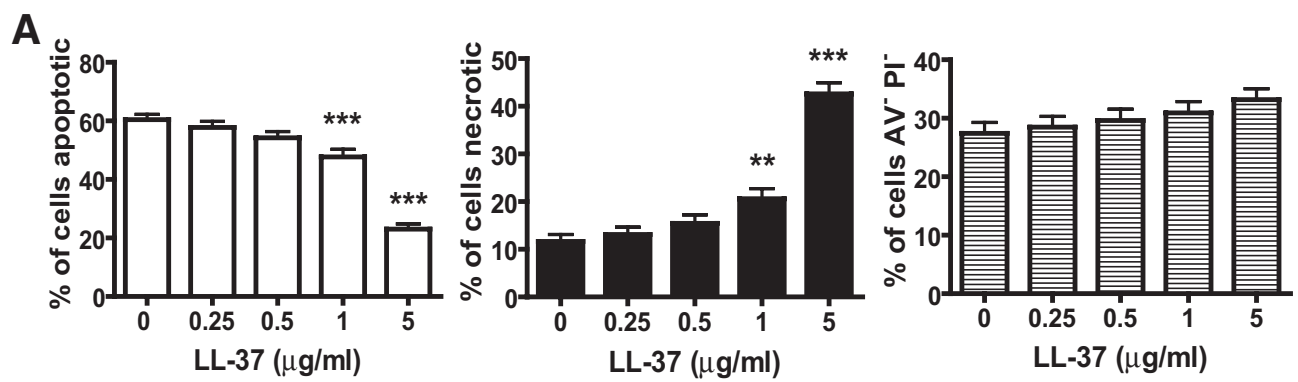

B
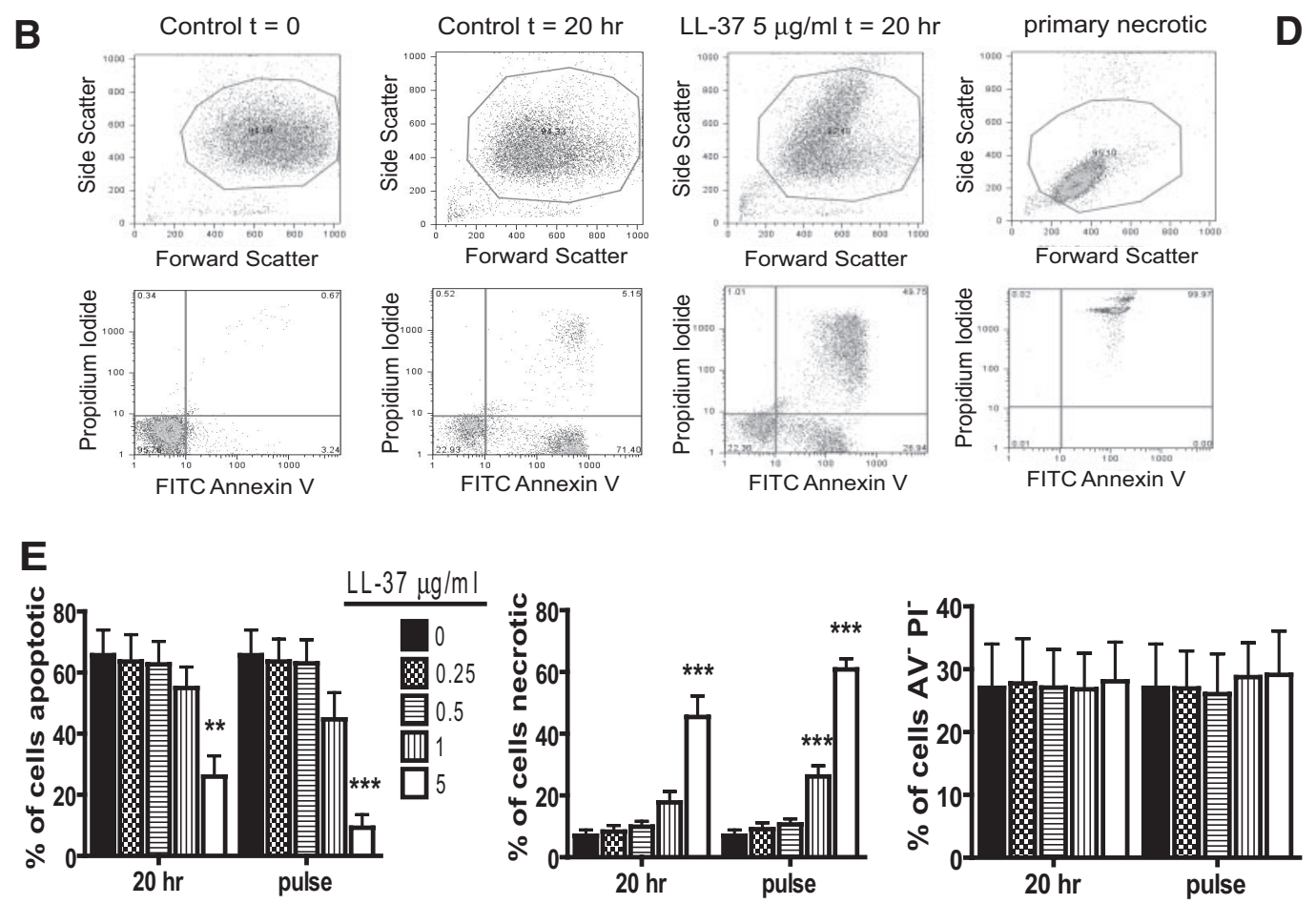

different donors for each condition, performed in triplicate. Significance was assessed by one-way ANOVA with Bonferroni's multiple comparison test comparing each treatment with control; **, $P \leq 0.01$; ***, $P \leq 0.001$. (B) Representative FACS plots. (C and D) Representative TEM images of (C) untreated, apoptotic PMN and (D) PMN exposed to $5 \mu \mathrm{g} / \mathrm{ml} \mathrm{LL}-37$. Arrows indicate examples of necrotic PMN. (E) Freshly isolated human PMN were incubated for $20 \mathrm{~h}$ over a range of LL-37 concentrations (20 h samples) or incubated for $20 \mathrm{~h}$ in the absence of LL-37 followed

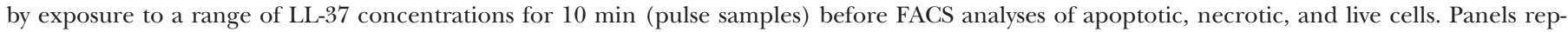

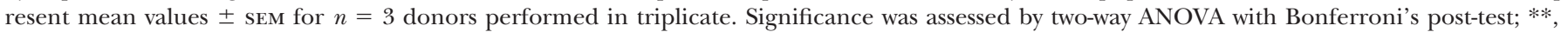
$P \leq 0.01 ; * * *, P \leq 0.001$, compared with untreated control. 


\section{Interaction of LL-37 with known modulators of PMN apoptosis}

To investigate whether LL-37 can interact with and modulate the effects of known modifiers of PMN apoptosis pathways, cells were incubated with LL-37 in the presence or absence of GM-CSF (a PMN survival factor [42]) or R-Roscovitine (a cyclin-dependent kinase inhibitor and inducer of PMN apoptosis [9]). GM-CSF reduced PMN apoptosis significantly at $20 \mathrm{~h}$, increasing the proportion of live cells with no effect on necrosis (Fig. 2A). Concomitant treatment with $5 \mu \mathrm{g} / \mathrm{ml} \mathrm{LL}-37$ had no effect on the capacity of GM-CSF to promote cell survival but significantly $(P<0.05)$ increased the proportion of necrotic cells with a reciprocal loss of apoptotic cells when compared with GM-CSF alone (Fig. 2A). R-Roscovitine induced PMN apoptosis significantly at $6 \mathrm{~h}$ with minimal necrosis (Fig. 2B). LL-37 alone $(\leq 25 \mu \mathrm{g} / \mathrm{ml})$ had no effect on cell death at this timepoint. Concomitant LL-37 treatment had no effect on the capacity of $R$-Roscovitine to induce cell death but significantly $(P<0.01)$ increased the proportion of necrotic cells in a dosedependent manner with a reciprocal loss of apoptotic cells when compared with $R$-Roscovitine alone (Fig. 2B). These data demonstrate no interaction with these direct modifiers of PMN apoptosis, but LL-37 induced secondary necrosis, relating in magnitude to the extent of induction of apoptosis.

In addition, studies were performed to assess the impact of LL-37 (a well-characterized antiendotoxic agent [15]) on the antiapoptotic effects of LPS in PMN [43]. LPS promoted PMN survival (Fig. 2C) significantly, inhibiting apoptosis without inducing necrosis (Fig. 2D). Concomitant incubation with LL-37 inhibited this effect significantly in a dose-dependent manner. LL-37 (5 $\mu \mathrm{g} / \mathrm{ml})$ blocked the pro-survival effects of LPS completely and significantly increased the proportion of dead cells that were necrotic $(P<0.01)$. However, the capacity of $5 \mu \mathrm{g} / \mathrm{ml}$ LL-37 to induce secondary necrosis was diminished significantly by LPS $(P<0.001)$. These data demonstrate LL-37mediated inhibition of the antiapoptotic effects of LPS and suggest a mutually inhibitory interaction with LPS diminishing LL-37-induced secondary necrosis.

\section{LL-37-mediated induction of secondary necrosis is conserved in mCRAMP and C-terminal partial peptides and is not primarily charge-dependent}

To examine the important characteristics of LL-37 for the capacity to induce secondary necrosis, FACS-based studies were performed using a scrambled LL-37 peptide (with conserved charge but altered amino acid sequence), the murine homologue mCRAMP, and a panel of sixteen 22-mer partial peptides spanning the sequence of LL-37 [37]. Incubation of PMN with scrambled LL-37 had no effect, whether exposed over $20 \mathrm{~h}$ or as a final 10-min pulse (Fig. 3A). In contrast, mCRAMP exposure closely replicated the effects of LL-37 with significant, dose-dependent induction of secondary necrosis (Fig. 3B). Exposure to N-terminal 22-mer partial LL-37 peptides (from the peptide incorporating aa 1-22 of LL-37 through that spanning aa 10-31) had no significant effects (Fig. 3C). In contrast, C-terminal partial peptides (from the peptide incorporating aa 11-32 through that spanning aa 16$37)$ induced significant secondary necrosis $(P<0.01)$ in the absence of effects on live cells but to a lesser extent than fulllength LL-37. This identified a putative minimal core functional region for induction of secondary necrosis spanning aa 16-32. The effects of these peptides showed no correlation with charge, which ranged from +3 to +6 . These data demonstrate that the capacity to induce PMN secondary necrosis is evolutionarily conserved between mouse and human cathelicidin, is not primarily dependent on peptide charge, and is retained by C-terminal but not N-terminal-truncated peptides of LL-37.
A
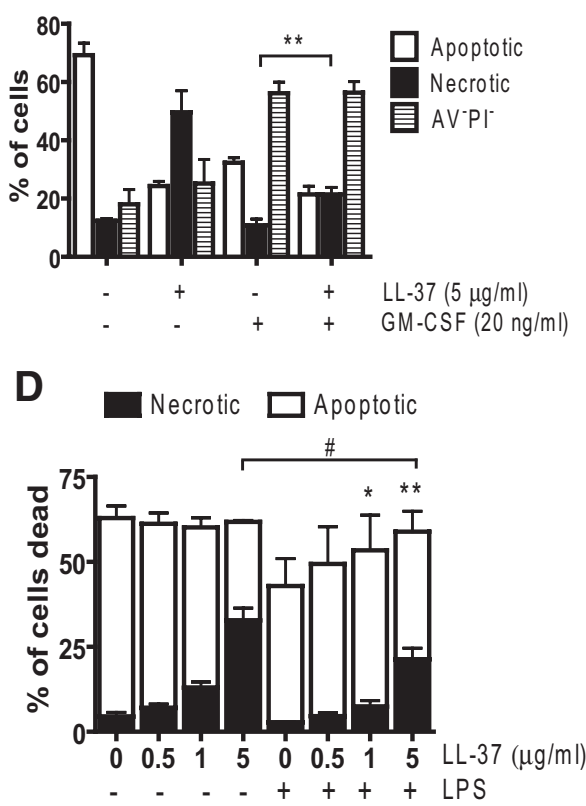

B

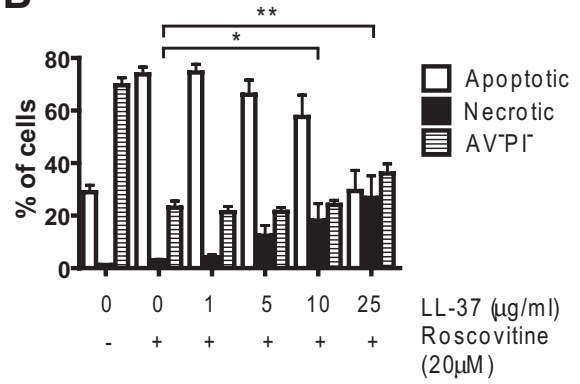

Figure 2. LL-37 exposure of PMN in the presence of modifiers of apoptotic pathways. Freshly isolated human PMN were incubated with LL-37 (at the concentrations indicated) for $20 \mathrm{~h}$ in the presence or absence of $20 \mathrm{ng} / \mathrm{ml} \mathrm{GM-CSF}$ (A), for $6 \mathrm{~h}$ in the presence or absence of $20 \mu \mathrm{M}$ $R$-Roscovitine (B), or for $20 \mathrm{~h}$ in the presence or absence of $500 \mathrm{ng} / \mathrm{ml} \mathrm{E}$. coli LPS (C and D). Cell death was examined by FACS analyses. Figures represent mean values \pm SEM for $n \geq 3$ donors performed in triplicate. Significance was assessed by one-way ANOVA with Bonferroni's multiple comparison test comparing each treatment with control; *, $P \leq 0.05$; **, $P \leq 0.01$, for necrotic (A, B, and D) or viable (C) cells in LL-37-treated samples compared with controls without LL-37 in the presence of (A) GM-CSF, (B) R-Roscovitine, or (C) LPS;,$P<0.001$, for necrotic (D) or viable $(\mathrm{C})$ cells in LPS-treated samples compared with controls without LPS in the comparable concentration of LL-37. 
Figure 3. Peptide specificity in the induction of PMN secondary necrosis. Freshly isolated human $\mathrm{PMN}$ were incubated with (A) a range of concentrations of scrambled LL-37 peptide for $20 \mathrm{~h}$, or for $10 \mathrm{~min}$ after $20 \mathrm{~h}$ incubation in the absence of peptide (pulse); $n=3$ donors performed in triplicate; (B) a range of concentrations of mCRAMP peptide; $n=$ 16 donors performed in triplicate; or (C) $5 \mu \mathrm{g} / \mathrm{ml}$ partial LL-37 peptides from a panel of 16 overlapping 22 -mers using $\mathrm{N}$ terminal peptide (aa 1-22), then peptide spanning aa 2-23, and so on through C-terminal peptide (aa 16-37) or full-length LL-37; $n=3$ donors performed in triplicate. Peptides p1, p2, and p3 are identified. Cell death was examined by FACS analyses as described. Figures represent mean values \pm sEm. Significance was assessed by one-way ANOVA with Bonferroni's multiple comparison test comparing each treatment with control; **, $P \leq 0.01$; ***, $P \leq 0.001$
A
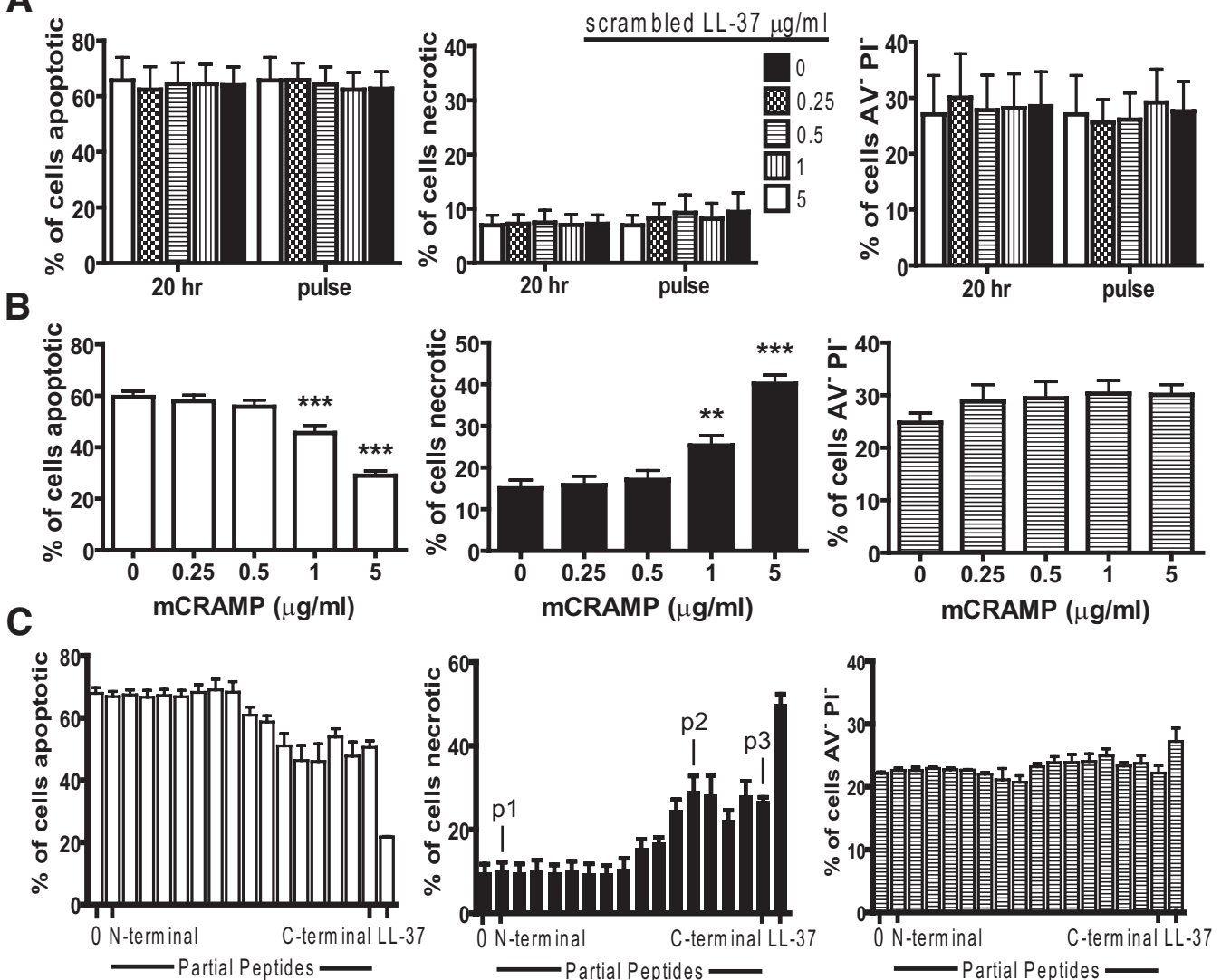

LL-37-induced secondary necrosis of apoptotic PMN does not inhibit macrophage efferocytosis

To determine whether macrophage ingestion of dead PMN was altered by LL-37-mediated secondary necrosis, ingestion of LL-37-treated PMN was studied using MDM by light microscopic enumeration (Fig. 4A). Confirmatory studies were performed using FACS analyses of MDM to determine ingestion of labeled PMN (Fig. 4B). In both studies, positive control dexamethasone-primed macrophages (shown previously to have increased capacity for apoptotic PMN ingestion [40]) were used. LL-37-mediated induction of secondary necrosis had no significant effects on the magnitude of PMN ingestion by MDM, even at $25 \mu \mathrm{g} / \mathrm{ml} \mathrm{LL}-37$ (a concentration at which $\sim 80 \%$ of dead cells are necrotic [10]).

\section{LL-37-induced secondarily necrotic PMN do not induce proinflammatory macrophage responses}

The interaction of apoptotic PMN and macrophages can induce anti-inflammatory macrophage responses and inhibit LPS-induced proinflammatory cytokine responses [5]. In contrast, necrotic cells are suggested to induce proinflammatory responses [44]. To examine the effects of LL-37-mediated PMN secondary necrosis, MDM cytokine responses to these cells were evaluated at $18 \mathrm{~h}$ after exposure. To separate the effects of any residual, functional LL-37 in the media from the effects of the dead PMN and of the cell bodies from the cellular contents released from secondarily necrotic cells, PMN were incubated for $20 \mathrm{~h}$ at a range of concentrations of LL-37, and MDM were then exposed to LL-37-treated PMN, resuspended in fresh serum-free media, unwashed LL-37-treated PMN in their original media, supernatant from LL-37-treated PMN alone, or media without PMN as a control.

MDM exposed to control apoptotic PMN, PMN incubated for $20 \mathrm{~h}$ with LL-37 $(\leq 25 \mu \mathrm{g} / \mathrm{ml})$, or the supernatants from these cells did not produce detectable levels of TNF- $\alpha$, IL-6, IL-10, IL-12p70, or IL-1 $\beta$ (Fig. 5, and data not shown), and there were no significant differences between responses to LL37-treated and control apoptotic PMN. These data suggest that LL-37-induced secondarily necrotic PMN are not proinflammatory to macrophages nor release effective, proinflammatory contents into the supernatant.

\section{LL-37-induced secondarily necrotic PMN have anti- inflammatory effects on macrophages}

To determine the effect of these cells in the context of proinflammatory stimuli, MDM were exposed concomitantly to 10 ng/ml E. coli LPS. Treatment of MDM with LPS alone stimulated significant production of TNF- $\alpha$, IL-6, and IL-10 (but not IL-12p70 or IL-1 $\beta$ ). In keeping with previous reports [5], the LPS-induced proinflammatory response was reduced by the addition of control apoptotic PMN in serum-free media with significant inhibition $(P<0.01)$ of TNF- $\alpha$ and IL-6 (Fig. 6A). However, these control apoptotic cells had no significant effect on LPS-induced IL-10 production (with considerable donor 

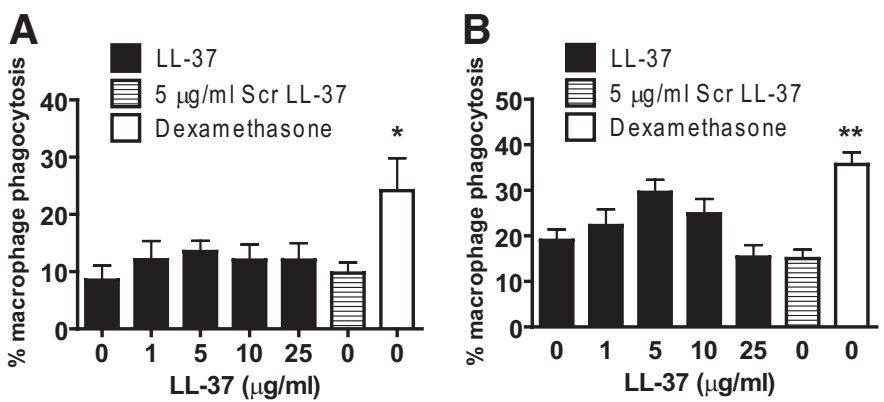

Figure 4. Macrophage phagocytosis of LL-37-induced secondarily necrotic PMN. PMN were incubated previously for $20 \mathrm{~h}$, with or without LL-37 (or scrambled LL-37) at the stated concentrations, and then incubated with hMDM for $1 \mathrm{~h}$ before removal of noningested PMN. Phagocytosis was assessed by (A) light microscopy, counting the proportion of MDM peroxidase-positive cells; $n=3$ donors for each condition and $n=2$ replicates/experiment; or (B) flow cytometric analyses, evaluating the proportion of MDM ingesting Cell Tracker Greenstained PMN; $n \geq 3$ donors for each condition, with $n=2$ replicates/ experiment. As a positive control, wells of adherent monocytes were also cultured in the presence of $1 \mu \mathrm{M}$ dexamethasone for 5 days to up-regulate MDM phagocytosis of dead PMN. Significance was assessed by one-way ANOVA with Bonferroni's multiple comparison test comparing each treatment with control; *, $P \leq 0.05$; **, $P \leq 0.01$.

variation). Contrary to expectation, when PMN, incubated previously for $20 \mathrm{~h}$ with LL-37 to induce secondary necrosis, were resuspended in fresh, serum-free media and used, these cells also inhibited LPS-induced TNF- $\alpha$ and IL- 6 responses. The effect of cells incubated previously with $5 \mu \mathrm{g} / \mathrm{ml}$ LL-37 to induce secondary necrosis was not significantly different than control apoptotic cells (Fig. 6A). However, significantly greater inhibition of LPS-induced TNF- $\alpha(P<0.01)$ was observed in response to cells incubated previously with $25 \mu \mathrm{g} / \mathrm{ml}$ LL-37 (Fig. 6A), in which the largest induction of secondary necrosis is evident. In addition, in contrast to control apoptotic cells, a trend toward diminished, LPS-induced MDM IL-10 responses was observed in response to these secondarily necrotic cells (Fig. 6A). Exposure of MDM to control apoptotic PMN in their original supernatant (Fig. 6B) had no effect on the LPSinduced production of TNF- $\alpha$, IL- 6 , or IL-10 by MDM and was essentially the same as exposure to the supernatant alone (data not shown). In contrast, exposure to unwashed, LL-37treated PMN in their original supernatant did inhibit the LPSinduced production of TNF- $\alpha(P<0.001)$, IL-6 $(P<0.05)$, and IL-10 by MDM (Fig. 6B). This effect could be replicated using supernatants alone (data not shown) but was not observed using cells treated with scrambled LL-37 (Fig. 6B). In addition, fresh LL-37, added directly to LPS-stimulated MDM in the absence of PMN, was able to replicate this inhibitory effect (Fig. $6 \mathrm{~B})$, indicating that the antiendotoxic effects of remaining, active LL-37 in the original supernatant may be responsible for the results observed in these latter studies. To determine whether the loss of inhibitory activity of dead PMN in their original supernatant related to cellular products or serum within the original media, $20 \mathrm{~h}$ PMN, washed and resuspended in fresh serum-containing media, were used. These cells (control and LL-37-treated) lost the capacity to inhibit LPS-induced MDM TNF- $\alpha$ production (Fig. 7A), implicating an unidentified serum-factor and demonstrating that washed, LL-37-treated cells did not have sufficient residual LL-37 to be directly antiendotoxic.

To confirm that the anti-inflammatory effects of LL-37-induced secondarily necrotic PMN were independent of the antiendotoxic effects of the peptide, rCD40L and rIFN- $\gamma$ treatment was used to activate MDM, rather than LPS. Controlapoptotic and LL-37-induced secondarily necrotic PMN were capable of significantly $(P<0.001)$ inhibiting the resultant TNF- $\alpha$ production (Fig. 7B).

In addition, the impact of three 22-mer partial LL-37 peptides was evaluated. N-terminal peptide $\mathrm{p} 1$ induced no PMN secondary necrosis (Fig. 3C) and had no direct antiendotoxic effects when applied to LPS-treated MDM (Fig. 7C). C-terminal peptides p2 and p3 induced significant PMN secondary necrosis (Fig. 3C), but whereas p2 had direct, significant antiendotoxic effects $(P<0.05)$, p3 did not (Fig. 7C). When PMN, incubated previously for $20 \mathrm{~h}$ with these peptides, were resuspended in fresh serum-free media, these cells were all capable of mediating a significant $(P<0.01)$ inhibition of LPS-induced MDM TNF- $\alpha$ production, identical to control cells (Fig. 7D). However, when used in their original media, the effects of these cells replicated the direct, antiendotoxic capacity of the peptide with which they had been treated (Fig. 7C). macrophages alone

macrophages + PMN in supernatant
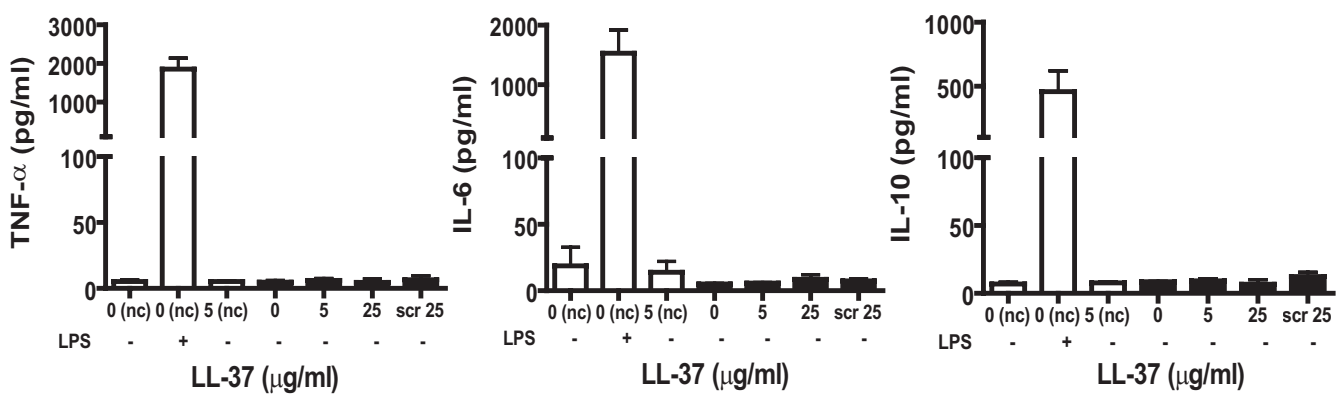

Figure 5. LL-37-induced secondarily necrotic PMN are not proinflammatory for macrophages. $\mathrm{Hu}$ man PMN were incubated for $20 \mathrm{~h}$ in the presence or absence of LL-37 or scrambled LL-37 at the concentrations indicated and used unwashed in the IMDM $+10 \%$ FCS media supernatant, in which they had been incubated. hMDM were incubated with these PMN or incubated without PMN (nc) in the presence or absence of LL-37 or 10 $\mathrm{ng} / \mathrm{ml}$ E. coli 0111:B4 LPS as a positive control. Supernatants were evaluated for cytokine responses. 
Figure 6. LL-37-induced secondarily necrotic PMN retain anti-inflammatory properties. Human PMN were incubated for $20 \mathrm{~h}$ in the presence or absence of LL-37 or scrambled LL-37 at the concentrations indicated. PMN were resuspended in serum-free X-vivo 10 media (A) or used unwashed in the IMDM $+10 \%$ FCS media supernatant, in which they were incubated overnight (B). MDM were incubated with these PMN, with concomitant exposure to $10 \mathrm{ng} / \mathrm{ml}$ E. coli 0111:B4 LPS for $18 \mathrm{~h}$. LPStreated MDM without PMN, in the presence or absence of LL-37, were also studied as controls. Supernatants were evaluated for cytokine responses. Significance was assessed by one-way ANOVA with Bonferroni's multiple comparison test; $n=9$ donors $(\mathrm{TNF}-\alpha) ; n=5$ donors (IL-6/IL-10); *, $P \leq$ 0.05 ; **, $P \leq 0.01$; ***, $P \leq 0.001$, compared with MDM exposed to LPS in the absence of PMN under the same conditions; ${ }^{\# \#}, P \leq 0.01$; ${ }^{\# \#,} P \leq 0.001$, compared with MDM exposed to control apoptotic PMN untreated with LL-37.
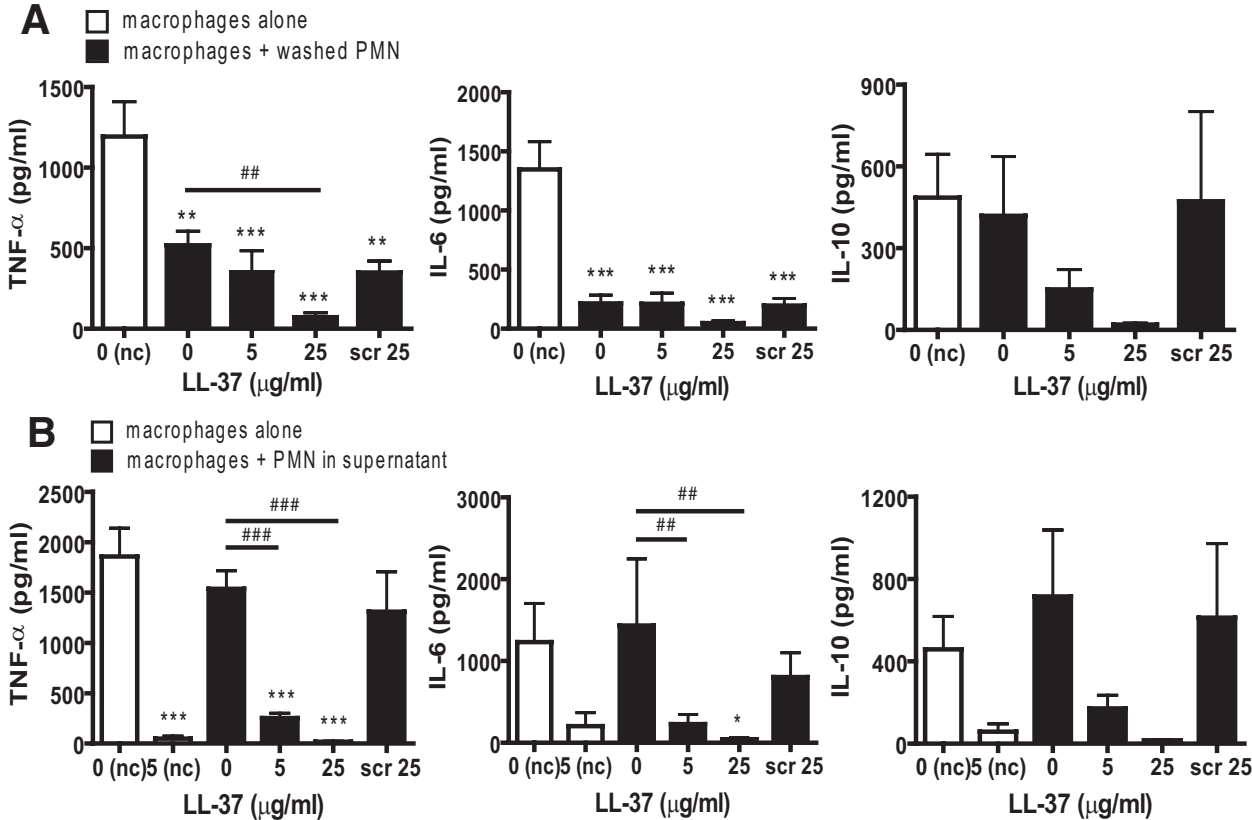

These data demonstrate the effect of residual peptide in the original media, show that functional peptide is not carried over in washed cells, and demonstrate that these dead PMN can inhibit LPS-induced MDM cytokine production, irrespective of the degree of peptide-induced secondary necrosis. These data demonstrate that the inhibition of activated MDM proinflammatory cytokine production mediated by apoptotic PMN is not inhibited and may even be enhanced by LL-37-mediated induction of secondary necrosis of these apoptotic PMN. Furthermore, the intracellular contents released by these cells are not actively proinflammatory or can be inhibited by the effects of LL-37.

\section{LL-37-mediated secondary necrosis can induce the release of PMN granule contents}

To determine the effect of LL-37-induced secondary necrosis of apoptotic PMN on the azurophilic (primary) granules, the release of MPO in response to LL-37 was quantified at $20 \mathrm{~h}$. MPO release was not detected above background for this timepoint following exposure to $\leq 10 \mu \mathrm{g} / \mathrm{ml} \mathrm{LL}-37$ (concentrations at which substantial secondary necrosis occurred) or in response to scrambled LL-37 (Fig. 8). However, significant levels of MPO were observed in response to $\geq 25 \mu \mathrm{g} / \mathrm{ml} \mathrm{LL}-37$ $(P<0.01)$ at levels approaching $40 \%$ of total MPO released by
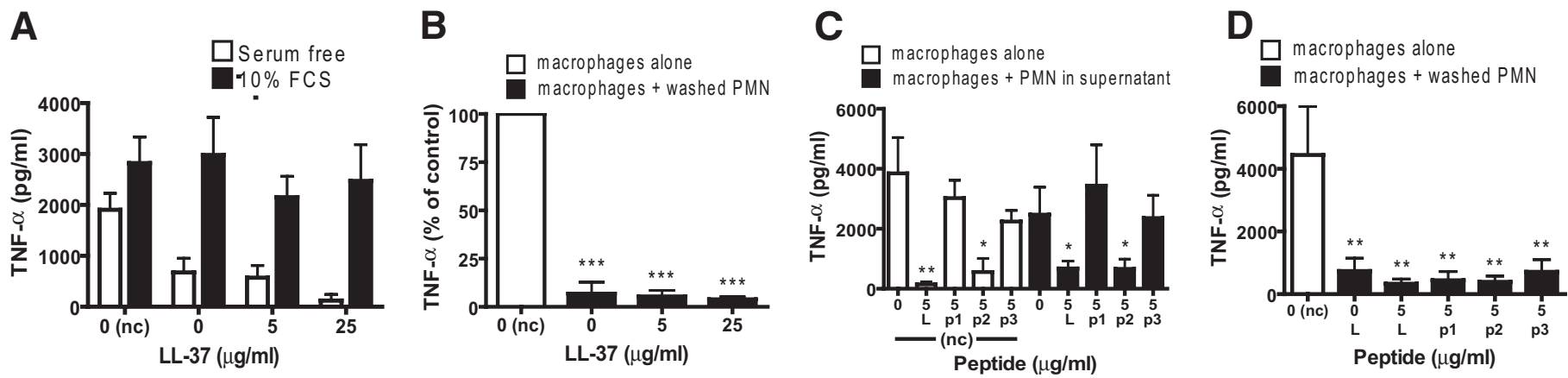

Figure 7. The anti-inflammatory properties LL-37-induced, secondarily necrotic PMN are independent of peptide antiendotoxic activity. Human PMN were incubated for $20 \mathrm{~h}$ in the presence or absence of LL-37 or partial peptides p1, p2, or p3 at the concentrations indicated. PMN were resuspended in X-vivo 10 media with $10 \%$ FCS (A), resuspended in serum-free X-vivo 10 media (B and D), or used unwashed in the IMDM + $10 \%$ FCS media supernatant, in which they were incubated overnight $(\mathrm{C})$. MDM were incubated with these PMN, with concomitant exposure to $10 \mathrm{ng} / \mathrm{ml}$ E. coli 0111:B4 LPS (A, C, and D) or $3 \mu \mathrm{g} / \mathrm{ml} \mathrm{rhCD} 40 \mathrm{~L}+5 \mathrm{ng} / \mathrm{ml} \mathrm{rhIFN}-\gamma$ (B) for $18 \mathrm{~h}$. Activated MDM without PMN, in the presence or absence of peptides, were also studied as controls and to evaluate direct antiendotoxic activity. Supernatants were evaluated for cytokine responses. Significance was assessed by one-way ANOVA with Bonferroni's multiple comparison test; $n \geq 3$ donors; *, $P \leq 0.05$; **, $P \leq 0.01$; ***, $P \leq 0.001$, compared with activated MDM in the absence of PMN under the same conditions. 


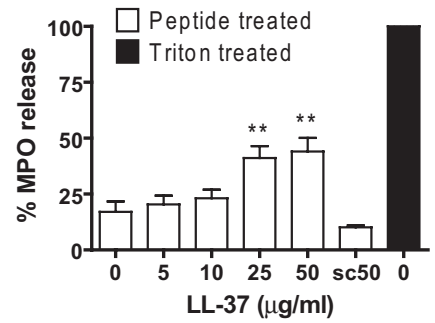

Figure 8. LL-37-induced secondary necrosis of PMN can release granule contents. Isolated human PMN were incubated for $20 \mathrm{~h}$ with a range of concentrations of LL-37 or $50 \mu \mathrm{g} / \mathrm{ml}$ scrambled LL-37 (sc50). The concentration of MPO in the supernatants was evaluated as a percentage of total MPO release after lysis of fresh control PMN using $0.1 \%$ Triton $\mathrm{X}-100$. Significance was assessed by one-way ANOVA with Bonferroni's multiple comparison test; $n=7$ donors; **, $P \leq$ 0.01, compared with untreated PMN.

lysis with Triton X-100. These data suggest that although LL37-induced secondary necrosis of apoptotic PMN does not lead directly to the release of granule contents over this time scale, higher concentrations of LL-37 are able to destabilize granules and lead to the release of their potentially damaging contents.

\section{DISCUSSION}

PMN are key cells of the innate immune system. The appropriate regulation of PMN function, death, and clearance is critical to effective control of inflammation, and dysregulation of these processes has been implicated in disease pathogenesis. Cell death by apoptosis, followed by efferocytosis by professional phagocytic cells, is proposed to enable safe PMN removal without the release of harmful intracellular contents to inhibit proinflammatory responses and to promote anti-inflammatory responses to enhance resolution [3]. In contrast, cell death by necrosis (whether primary necrosis or secondary necrosis of apoptotic PMN that have not been cleared) is proposed to be proinflammatory. We demonstrate that the human cathelicidin LL-37 is a potent inducer of secondary necrosis in $\mathrm{PMN}$, which have undergone prior apoptosis, and evaluate the impact of this process on macrophage inflammatory responses.

We demonstrate that the ingestion of LL-37-induced secondarily necrotic PMN was not a proinflammatory event. This process did not promote the release of proinflammatory cytokines by macrophages and was indistinguishable from the macrophage response to apoptotic cells. Furthermore, these secondarily necrotic PMN were actively anti-inflammatory, demonstrating that the capacity of apoptotic PMN to inhibit LPS-induced proinflammatory cytokine production by macrophages was undiminished by LL-37-induced secondary necrosis. Indeed, this anti-inflammatory effect was actually enhanced in response to PMN with the most extensive secondary necrosis. Although the anti-inflammatory activity of unwashed, LL-37treated apoptotic PMN was a result of the antiendotoxic properties of the remaining, functional LL-37 in the supernatant, washed cells retained the anti-inflammatory capacity of control apoptotic cells, even after treatment conditions $(25 \mu \mathrm{g} / \mathrm{ml}$
LL-37 for $20 \mathrm{~h}$ ) in which $\sim 80 \%$ of dead PMN have undergone secondary necrosis [10]. These data suggest functional equivalence, irrespective of membrane integrity, of apoptotic PMN and LL-37-induced secondarily necrotic cells in this system. A previous report has demonstrated potential functional dominance of apoptotic cells over primary necrotic cells [45]. We cannot exclude a dominant role for the remaining membraneintact apoptotic cells in our system. However, the significantly enhanced anti-inflammatory effects induced by PMN, with the greatest proportion of secondary necrosis, indicate that the anti-inflammatory activity of apoptotic PMN can in fact be potentiated by LL-37-induced secondary necrosis. Whether this applies to PMN necrosis induced in other ways and the mechanisms involved remains to be determined. However, exposure to a concentration of LL-37, sufficient to induce PMN granule content release, appeared to be necessary to generate secondary necrosis capable of potentiating the anti-inflammatory effects. This indicates that induction of necrosis per se is not sufficient and implicates a possible role for the release of endogenous LL-37 or other anti-inflammatory agents from PMN granules. Irrespective, it is clear that LL-37-induced secondary necrosis did not compromise the anti-inflammatory effects of the dead cells nor confer proinflammatory properties on them. Furthermore, any proinflammatory mediators released by secondarily necrotic PMN into the supernatant were unable to initiate or potentiate macrophage production of the cytokines studied in the presence of LL-37.

Whereas apoptosis has been viewed as anti-inflammatory and inducing immune-tolerance, necrosis has been considered a proinflammatory and immunogenic form of cell death. However, recent studies have suggested that this axiom is oversimplified [46]. Apoptotic Jurkat T cells are reported to be equally potent in modulating macrophage MAPK pathways, irrespective of membrane integrity [47], and the membranes of apoptotic and primary necrotic PMN have been shown to inhibit TNF- $\alpha$ production by activated macrophages [44]. In addition, apoptosis can neutralize potential intracellular danger signals, such as high-mobility group box-1 protein, via caspase-activated mitochondrial reactive oxygen species production [48]. Thus, the release of intracellular contents from apoptotic cells having undergone secondary necrosis may not be equivalent to the proinflammatory contents of primary necrotic cells, an hypothesis that would be compatible with our data.

We demonstrate that LL-37-induced PMN secondary necrosis had no impact on the magnitude of ingestion of dead PMN by macrophages, consistent with previous reports $[44,45]$. Efferocytosis is a complex process with multiple receptors and adaptors proposed [3], independent from the anti-inflammatory effects initiated by apoptotic cells [49]. We cannot exclude the possibility that the mechanism of ingestion of these secondary necrotic PMN and apoptotic PMN may be different, but comparable levels of uptake suggest that LL-37-mediated induction of PMN secondary necrosis in vivo would not inhibit the clearance of dead PMN.

Irrespective of the impact of secondary necrosis on the clearance of dead PMN or macrophage cytokine responses, the loss of PMN membrane integrity presents the additional 
threat of the release of harmful intracellular contents, including granule contents such as neutrophil elastase, cathepsin G, MPO, and gelatinase [50]. In contrast to previous TEM-based observations [38], our data demonstrate that high concentrations of LL-37 induced the release of MPO from the azurophilic granules. Interestingly, this was not observed at lower LL-37 concentrations, at which significant induction of secondary necrosis was observed nevertheless. This suggests that LL37-induced secondary necrosis did not disrupt granule integrity per se but that high concentrations of LL-37 $(\geq 10 \mu \mathrm{g} / \mathrm{ml})$ had the capacity to damage granule membranes in addition to apoptotic outer membranes. The consequences of such an effect in a rapidly resolving acute infection may contrast with those in a chronic inflammatory process associated with high levels of LL-37. Indeed, increased hCAP-18/LL-37 concentrations in cystic fibrosis lung disease (detected at up to $\sim 15$ $\mu \mathrm{g} / \mathrm{ml}$ in BALF from patients without recent infectious exacerbation) were correlated with increased lung damage [34], and raised pulmonary LL-37 levels are associated with bronchiolitis obliterans syndrome in the recipients of lung transplants [36]. In addition, LL-37 has been proposed recently to contribute to the pathogenesis of psoriasis [35], and the concentration of hCAP-18/LL-37 was reported to be $\sim 1.5 \mathrm{mg} / \mathrm{ml}$ in psoriatic skin lesions [51]. These estimates of in vivo peptide concentrations do not take into account the recent observation that the ratio of active LL-37 to full-length precursor hCAP-18 varied considerably between donors in the inflamed lung [36]. Nevertheless, at these concentrations, extensive induction of secondary necrosis of apoptotic PMN, with the release of PMN granule contents, could be generated by exposure to LL-37 in vivo. Thus, the potentially detrimental effects of LL-37-mediated induction of PMN secondary necrosis could have significance in chronic disease processes.

The potential consequences of PMN granule release may be of particular significance for the ongoing development of CHDP as therapeutic agents for infectious and inflammatory diseases. A greater knowledge of the capacity of these peptides to modulate inflammation and the peptide attributes that confer them will have important implications. We have demonstrated recently that the capacity of LL-37 to induce secondary necrosis of apoptotic cells is not specific to PMN [41] and now additionally define a core functional region and describe interaction with other modifiers of cell death.

We demonstrate that LL-37-induced secondary necrosis of PMN occurred rapidly, within minutes of exposure of an apoptotic PMN to the peptide. The specific membrane alterations that make these apoptotic cells acutely susceptible to damage by LL-37 and the nature of this interaction remain unclear, but the process has been proposed recently to be energy-independent [38] and independent of known LL-37 receptors [41]. Our data demonstrate that this property was conserved in the murine ortholog mCRAMP, and the effect was not dependent primarily on peptide charge (with no effects seen for a scrambled sequence peptide with the same charge) and was retained partially by $\mathrm{C}$-terminal, but not $\mathrm{N}$-terminal partial LL-37 peptides. These latter studies, using truncated partial peptides, shown previously to be poorly antiendotoxic [37], identified a minimal core-functional region for induction of secondary necrosis by LL-37, spanning aa 16-32. This may indicate an important motif or be related to the more amphipathic nature of the peptides spanning this region. Interestingly, the region 17-32 has been identified previously as the core antimicrobial region [52]. This suggests a possible conservation of mechanism between the direct microbicidal effects of LL-37, for which amphipathicity is critical [52], and the capacity to induce PMN secondary necrosis. However, it is noteworthy that whereas core LL-37 peptide 17-32 had enhanced microbicidal function compared with full-length LL-37, our partial peptides had diminished capacity to induce secondary necrosis. This has important implications for the development of therapeutic peptides and in consideration of the possible in vivo activities of shorter-form cleavage products of hCAP-18, identified previously in the skin [53]. Further study of our partial peptides will enable dissection of the various properties of LL-37.

In conclusion, we demonstrate that the human cathelicidin LL-37 is a potent inducer of secondary necrosis of apoptotic PMN, with the potential to alter the profile of PMN cell death at sites of infection and inflammation. Our data give novel insights into the potential effects of PMN secondary necrosis, suggesting that LL-37-mediated secondary necrosis of PMN does not have proinflammatory effects on macrophages and can even potentiate the anti-inflammatory effects of efferocytosis. These data challenge the prevailing model that although apoptotic cells are anti-inflammatory to macrophages, necrotic cells (whether primary or secondary necrosis) are inherently proinflammatory. This has particular importance for the delayed clearance of the apoptotic cell hypothesis for chronic inflammation and implications for novel, anti-inflammatory strategies being developed based on our understanding the mechanisms controlling the resolution of inflammation. However, we also demonstrate that LL-37-induced secondary necrosis has the potential to induce the release of potentially harmful granule contents, which could have deleterious consequences for the host, particularly in chronic disease states. We demonstrate that this induction of secondary necrosis by LL-37 is not primarily charge-dependent, is partially retained by $\mathrm{C}$ terminal partial peptides, and is conserved in the murine ortholog. Further understanding of this mechanism and its physiological significance will assist the appropriate modification of synthetic analogs as novel therapeutics, illuminate possible roles in the pathogenesis of chronic disease, and advance our understanding of the impact of different cell death processes in the promotion and resolution of inflammation.

\section{ACKNOWLEDGMENTS}

This worked was funded by the Wellcome Trust and the Norman Salvesen Trust Emphysema Research Trust. D. J. D. is a Wellcome Trust Research Career Development Fellow (fellowship \#078265). The Swedish group was funded by grants from the Swedish Research Council, the King Gustav V 80-Year Foundation, and the Swedish State under the LUA/ALF agreement. The authors thank Stephen Mitchell, Fiona Rossi, Shonna Johnson, Katherine Miles, Tara Sheldrake, Jillian Ren- 
nie, Irini Bournazos, Stelios Bournazos, Dennis Ninaber, Sarah Fox, Andrew Leitch, Sylwia Michlewska, Sandra Franz, and Mark Marsden for technical assistance and Simon Brown, Ian Dransfield, Aisleen McColl, Robert Gray, Thomas Wilkinson, Kev Dhaliwal, Olga Lucia Moncayo Nieto, and Andy Conway Morris for valuable advice.

\section{REFERENCES}

1. Haslett, C. (1999) Granulocyte apoptosis and its role in the resolution and control of lung inflammation. Am. J. Respir. Crit. Care Med. 160, S5-11.

2. Leitch, A. E., Duffin, R., Haslett, C., Rossi, A. G. (2008) Relevance of granulocyte apoptosis to resolution of inflammation at the respiratory mucosa. Mucosal Immunol. 1, 350-363.

3. Savill, J., Dransfield, I., Gregory, C., Haslett, C. (2002) A blast from the past: clearance of apoptotic cells regulates immune responses. Nat. Rev. Immunol. 2, 965-975.

4. Voll, R. E., Herrmann, M., Roth, E. A., Stach, C., Kalden, J. R., Girkontaite, I. (1997) Immunosuppressive effects of apoptotic cells. Nature 390, $350-351$.

5. Fadok, V. A., Bratton, D. L., Konowal, A., Freed, P. W., Westcott, J. Y., Henson, P. M. (1998) Macrophages that have ingested apoptotic cells in vitro inhibit proinflammatory cytokine production through autocrine/ paracrine mechanisms involving TGF- $\beta$, PGE2, and PAF. J. Clin. Invest. 101, 890-898.

6. Huynh, M. L., Fadok, V. A., Henson, P. M. (2002) Phosphatidylserinedependent ingestion of apoptotic cells promotes TGF- $\beta 1$ secretion and the resolution of inflammation. J. Clin. Invest. 109, 41-50.

7. Serhan, C. N., Savill, J. (2005) Resolution of inflammation: the beginning programs the end. Nat. Immunol. 6, 1191-1197.

8. Bianchi, S. M., Dockrell, D. H., Renshaw, S. A., Sabroe, I., Whyte, M. K. (2006) Granulocyte apoptosis in the pathogenesis and resolution of lung disease. Clin. Sci. (Lond.) 110, 293-304.

9. Rossi, A. G., Sawatzky, D. A., Walker, A., Ward, C., Sheldrake, T. A., Riley, N. A., Caldicott, A., Martinez-Losa, M., Walker, T. R., Duffin, R., Gray, M., Crescenzi, E., Martin, M. C., Brady, H. J., Savill, J. S., Dransfield, I., Haslett, C. (2006) Cyclin-dependent kinase inhibitors enhance the resolution of inflammation by promoting inflammatory cell apoptosis. Nat. Med. 12, 1056-1064.

10. Barlow, P. G., Li, Y., Wilkinson, T. S., Bowdish, D. M., Lau, Y. E., Cosseau, C., Haslett, C., Simpson, A. J., Hancock, R. E., Davidson, D. J. (2006) The human cationic host defense peptide LL-37 mediates contrasting effects on apoptotic pathways in different primary cells of the innate immune system. J. Leukoc. Biol. 80, 509-520.

11. Nagaoka, I., Tamura, H., Hirata, M. (2006) An antimicrobial cathelicidin peptide, human CAP18/LL-37, suppresses neutrophil apoptosis via the activation of formyl-peptide receptor-like 1 and P2X7. J. Immunol. 176, 3044-3052.

12. Sorensen, O., Arnljots, K., Cowland, J. B., Bainton, D. F., Borregaard, N (1997) The human antibacterial cathelicidin, hCAP-18, is synthesized in myelocytes and metamyelocytes and localized to specific granules in neutrophils. Blood 90, 2796-2803.

13. Sorensen, O. E., Follin, P., Johnsen, A. H., Calafat, J., Tjabringa, G. S., Hiemstra, P. S., Borregaard, N. (2001) Human cathelicidin, hCAP-18, is processed to the antimicrobial peptide LL-37 by extracellular cleavage with proteinase 3. Blood 97, 3951-3959.

14. Bowdish, D. M., Davidson, D. J., Hancock, R. E. (2006) Immunomodulatory properties of defensins and cathelicidins. Curr. Top. Microbiol. Immunol. 306, 27-66.

15. Scott, M. G., Davidson, D. J., Gold, M. R., Bowdish, D., Hancock, R. E. (2002) The human antimicrobial peptide LL-37 is a multifunctional modulator of innate immune responses. J. Immunol. 169, 3883-3891.

16. Fukumoto, K., Nagaoka, I., Yamataka, A., Kobayashi, H., Yanai, T., Kato, Y., Miyano, T. (2005) Effect of antibacterial cathelicidin peptide CAP18/ LL-37 on sepsis in neonatal rats. Pediatr. Surg. Int. 21, 20-24.

17. De Yang, Chen, Q., Schmidt, A. P., Anderson, G. M., Wang, J. M., Wooters, J., Oppenheim, J. J., Chertov, O. (2000) LL-37, the neutrophil granule- and epithelial cell-derived cathelicidin, utilizes formyl peptide receptor-like 1 (FPRL1) as a receptor to chemoattract human peripheral blood neutrophils, monocytes, and T cells. J. Exp. Med. 192, 1069-1074.

18. Kurosaka, K., Chen, Q., Yarovinsky, F., Oppenheim, J. J., Yang, D. (2005) Mouse cathelin-related antimicrobial peptide chemoattracts leukocytes using formyl peptide receptor-like 1 /mouse formyl peptide receptor-like 2 as the receptor and acts as an immune adjuvant. J. Immunol. 174, 62576265 .

19. Elssner, A., Duncan, M., Gavrilin, M., Wewers, M. D. (2004) A novel P2X7 receptor activator, the human cathelicidin-derived peptide LL37, induces IL-1 $\beta$ processing and release. J. Immunol. 172, 49874994

20. Mookherjee, N., Brown, K. L., Bowdish, D. M., Doria, S., Falsafi, R., Hokamp, K., Roche, F. M., Mu, R., Doho, G. H., Pistolic, J., Powers, J. P.,
Bryan, J., Brinkman, F. S., Hancock, R. E. (2006) Modulation of the TLR mediated inflammatory response by the endogenous human host defense peptide LL-37. J. Immunol. 176, 2455-2464.

21. Niyonsaba, F., Someya, A., Hirata, M., Ogawa, H., Nagaoka, I. (2001) Evaluation of the effects of peptide antibiotics human $\beta$-defensins- $1 /-2$ and LL-37 on histamine release and prostaglandin $\mathrm{D}(2)$ production from mast cells. Eur. J. Immunol. 31, 1066-1075.

22. Heilborn, J. D., Nilsson, M. F., Kratz, G., Weber, G., Sorensen, O., Borregaard, N., Stahle-Backdahl, M. (2003) The cathelicidin anti-microbial peptide LL-37 is involved in re-epithelialization of human skin wounds and is lacking in chronic ulcer epithelium. J. Invest. Dermatol. 120, $379-$ 389.

23. Koczulla, R., Von Degenfeld, G., Kupatt, C., Krotz, F., Zahler, S., Gloe, T., Issbrucker, K., Unterberger, P., Zaiou, M., Lebherz, C., Karl, A., Raake, P., Pfosser, A., Boekstegers, P., Welsch, U., Hiemstra, P. S., Vogelmeier, C., Gallo, R. L., Clauss, M., Bals, R. (2003) An angiogenic role for the human peptide antibiotic LL-37/hCAP-18. J. Clin. Invest. 111, 1665-1672.

24. Davidson, D. J., Currie, A. J., Reid, G. S., Bowdish, D. M., MacDonald, K. L., Ma, R. C., Hancock, R. E., Speert, D. P. (2004) The cationic antimicrobial peptide LL-37 modulates dendritic cell differentiation and dendritic cell-induced $\mathrm{T}$ cell polarization. J. Immunol. 172, 1146-1156.

25. An, L. L., Yang, Y. H., Ma, X. T., Lin, Y. M., Li, G., Song, Y. H., Wu, K. F. (2005) LL-37 enhances adaptive antitumor immune response in a murine model when genetically fused with M-CSFR(J6-1) DNA vaccine. Leuk. Res. 29, 535-543.

26. Lau, Y. E., Bowdish, D. M., Cosseau, C. C., Hancock, R. E., Davidson, D. J. (2006) Apoptosis of airway epithelial cells: human serum sensitive induction by the cathelicidin LL-37. Am. J. Respir. Cell Mol. Biol. 34, 399409.

27. Aarbiou, J., Tjabringa, G. S., Verhoosel, R. M., Ninaber, D. K., White, S. R., Peltenburg, L. T., Rabe, K. F., Hiemstra, P. S. (2006) Mechanism of cell death induced by the neutrophil antimicrobial peptides $\alpha$-defensins and LL-37. Inflamm. Res. 55, 119-127.

28. Putsep, K., Carlsson, G., Boman, H. G., Andersson, M. (2002) Deficiency of antibacterial peptides in patients with morbus Kostmann: an observation study. Lancet 360, 1144-1149.

29. Nizet, V., Ohtake, T., Lauth, X., Trowbridge, J., Rudisill, J., Dorschner, R. A., Pestonjamasp, V., Piraino, J., Huttner, K., Gallo, R. L. (2001) Innate antimicrobial peptide protects the skin from invasive bacterial infection. Nature 414, 454-457.

30. Iimura, M., Gallo, R. L., Hase, K., Mivamoto, Y., Eckmann, L., Kagnoff, M. F. (2005) Cathelicidin mediates innate intestinal defense against colonization with epithelial adherent bacterial pathogens. J. Immunol. 174, 4901-4907.

31. Chromek, M., Slamova, Z., Bergman, P., Kovacs, L., Podracka, L., Ehren, I., Hokfelt, T., Gudmundsson, G. H., Gallo, R. L., Agerberth, B., Brauner, A. (2006) The antimicrobial peptide cathelicidin protects the urinary tract against invasive bacterial infection. Nat. Med. 12, $636-641$.

32. Schaller-Bals, S., Schulze, A., Bals, R. (2002) Increased levels of antimicrobial peptides in tracheal aspirates of newborn infants during infection. Am. J. Respir. Crit. Care Med. 165, 992-995.

33. Bals, R., Weiner, D. J., Moscioni, A. D., Meegalla, R. L., Wilson, J. M. (1999) Augmentation of innate host defense by expression of a cathelicidin antimicrobial peptide. Infect. Immun. 67, 6084-6089.

34. Chen, C. I., Schaller-Bals, S., Paul, K. P., Wahn, U., Bals, R. (2004) $\beta$-Defensins and LL-37 in bronchoalveolar lavage fluid of patients with cystic fibrosis. J. Cyst. Fibros. 3, 45-50.

35. Lande, R., Gregorio, J., Facchinetti, V., Chatterjee, B., Wang, Y. H., Homey, B., Cao, W., Wang, Y. H., Su, B., Nestle, F. O., Zal, T., Mellman, I., Schroder, J. M., Liu, Y. J., Gilliet, M. (2007) Plasmacytoid dendritic cells sense self-DNA coupled with antimicrobial peptide. Nature 449, 564 569.

36. Anderson, R. L., Hiemstra, P. S., Ward, C., Forrest, I. A., Murphy, D., Proud, D., Lordan, J., Corris, P. A., Fisher, A. J. (2008) Antimicrobial peptides in lung transplant recipients with bronchiolitis obliterans syndrome. Eur. Respir. J. 32, 670-677.

37. Nell, M. J., Tjabringa, G. S., Wafelman, A. R., Verrijk, R., Hiemstra, P. S., Drijfhout, J. W., Grote, J. J. (2006) Development of novel LL-37 derived antimicrobial peptides with LPS and LTA neutralizing and antimicrobial activities for therapeutic application. Peptides 27, 649-660.

38. Zhang, Z., Cherryholmes, G., Shively, J. E. (2008) Neutrophil secondary necrosis is induced by LL-37 derived from cathelicidin. J. Leukoc. Biol. 84 $780-788$.

39. Jersmann, H. P., Ross, K. A., Vivers, S., Brown, S. B., Haslett, C., Dransfield, I. (2003) Phagocytosis of apoptotic cells by human macrophages: analysis by multiparameter flow cytometry. Cytometry A 51, $7-15$.

40. Liu, Y., Cousin, J. M., Hughes, J., Van Damme, J., Seckl, J. R., Haslett, C., Dransfield, I., Savill, J., Rossi, A. G. (1999) Glucocorticoids promote nonphlogistic phagocytosis of apoptotic leukocytes. J. Immunol. 162, 36393646 .

41. Bjorstad, A., Askarieh, G., Brown, K. L., Christenson, K., Forsman, H. Onnheim, K., Li, H. N., Teneberg, S., Maier, O., Hoekstra, D., Dahlgren, 
C., Davidson, D. J., Bylund, J. (2009) The host defence peptide LL-37 selectively permeabilizes apoptotic leukocytes. Antimicrob. Agents Chemother. 53, 1027-1038.

42. Klein, J. B., Rane, M. J., Scherzer, J. A., Coxon, P. Y., Kettritz, R., Mathiesen, J. M., Buridi, A., McLeish, K. R. (2000) Granulocyte-macrophage colony-stimulating factor delays neutrophil constitutive apoptosis through phosphoinositide 3-kinase and extracellular signal-regulated kinase pathways. J. Immunol. 164, 4286-4291.

43. Sabroe, I., Prince, L. R., Jones, E. C., Horsburgh, M. J., Foster, S. J., Vogel, S. N., Dower, S. K., Whyte, M. K. (2003) Selective roles for Toll-like receptor (TLR) 2 and TLR4 in the regulation of neutrophil activation and life span. J. Immunol. 170, 5268-5275.

44. Fadok, V. A., Bratton, D. L., Guthrie, L., Henson, P. M. (2001) Differential effects of apoptotic versus lysed cells on macrophage production of cytokines: role of proteases. J. Immunol. 166, 6847-6854.

45. Cocco, R. E., Ucker, D. S. (2001) Distinct modes of macrophage recognition for apoptotic and necrotic cells are not specified exclusively by phosphatidylserine exposure. Mol. Biol. Cell 12, 919-930.

46. Krysko, D. V., D'Herde, K., Vandenabeele, P. (2006) Clearance of apoptotic and necrotic cells and its immunological consequences. Apoptosis 11, 17091726.

47. Patel, V. A., Longacre, A., Hsiao, K., Fan, H., Meng, F., Mitchell, J. E., Rauch, J., Ucker, D. S., Levine, J. S. (2006) Apoptotic cells, at all stages of the death process, trigger characteristic signaling events that are divergent from and dominant over those triggered by necrotic cells: implications for the delayed clearance model of autoimmunity. J. Biol. Chem. 281, 4663-4670.
48. Kazama, H., Ricci, J. E., Herndon, J. M., Hoppe, G., Green, D. R., Ferguson, T. A. (2008) Induction of immunological tolerance by apoptotic cells requires caspase-dependent oxidation of high-mobility group box-1 protein. Immunity 29, 21-32.

49. Lucas, M., Stuart, L. M., Zhang, A., Hodivala-Dilke, K., Febbraio, M., Silverstein, R., Savill, J., Lacy-Hulbert, A. (2006) Requirements for apoptotic cell contact in regulation of macrophage responses. J. Immunol. 177, 4047-4054.

50. Borregaard, N., Cowland, J. B. (1997) Granules of the human neutrophilic polymorphonuclear leukocyte. Blood 89, 3503-3521.

51. Ong, P. Y., Ohtake, T., Brandt, C., Strickland, I., Boguniewicz, M., Ganz, T., Gallo, R. L., Leung, D. Y. (2002) Endogenous antimicrobial peptides and skin infections in atopic dermatitis. N. Engl. J. Med. 347, 1151-1160.

52. Li, X., Li, Y., Han, H., Miller, D. W., Wang, G. (2006) Solution structures of human LL-37 fragments and NMR-based identification of a minimal membrane-targeting antimicrobial and anticancer region. J. Am. Chem. Soc. 128, 5776-5785.

53. Murakami, M., Lopez-Garcia, B., Braff, M., Dorschner, R. A., Gallo, R. L. (2004) Postsecretory processing generates multiple cathelicidins for enhanced topical antimicrobial defense. J. Immunol. 172, 3070-3077.

\section{KEY WORDS:}

cationic host defense peptide $\cdot$ antimicrobial peptide $\cdot$ innate immunity $\cdot$ inflammation $\cdot$ efferocytosis 